$\xi=-1$

\title{
Conducting Icos as a Modern Investment Approach for Implementation of Innovations for the Ukrainian Railway Transport
}

\author{
${\text { I. } \text { Zaitseva }^{1} \text {, M. Ieromina }}^{1}$, Y. Prudius ${ }^{1}$ \\ Ukrainian State University of Railway Transport \\ *Corresponding author E-mail: zaitsevairaida@ukr.net
}

\begin{abstract}
The Ukrainian railway transport is the leading branch in the national road transport complex. Until recently, the Ukrainian railways have been satisfying the transportation needs of the economy and the population. Today, the service life of the technical resource of railways is practically expired. Therefore, there is a threat that the railway transport fails to satisfy future transportation needs of the Ukrainian economy.

According to the accounting reports of Ukrzaliznytsya PJSC, at the end of 2016, the deterioration level of the fixed assets in the industry was $69.4 \%$. In the context of a constant budget shortfall, the most urgent issue for Ukrainian railways is focusing on activation of innovation activity. We believe that most of the schemes of the traditional economy in the 21 st century no longer work; therefore, alternatives should be searched for, the most obvious of which now is the cryptoeconomy with its decentralized system. The development and implementation of innovations in the Ukrainian railway industry requires new approaches to the system of financing innovations in the country; in this respect, ICO is a modern and promising method of attracting investments.
\end{abstract}

Keywords: Crowd funding technology; cryptology; ICO; implementation of innovations in the Ukrainian railway industry; sources of financing for innovation; the analysis of the financial and investment situation.

\section{Introduction}

The development of railway transport is closely related to the development of other sectors of the economy. The mobility behaviour of the population, the level of development of the production and trade determine the demand for its services. At the same time, the railway transport is a systemic factor since it affects the standards of living and the development of productive forces. The geopolitical position of Ukraine together with the multimodality of its high-tech transportation industry creates objective prerequisites for implementing the idea of a single transport space on the Eurasian continent.

The Ukrainian railway transport is the leading branch in the national road transport complex covering almost $82 \%$ of freight and $36 \%$ of passenger traffic carried by all modes of transport. In terms of the freight traffic, the Ukrainian railways rank fourth in the Eurasian continent, after the Chinese, Russian and Indian railways. The traffic flow of the Ukrainian railways is 3-5 times higher than that in the developed European countries.

Until recently, the Ukrainian railways have been satisfying the transportation needs of the economy and the population. This was achieved mainly due to the excessive technical capacities created in the USSR at the expense of centralized financing from the national budget. In the last more than 20 years, only the own funds of the railways have been invested into the renovation of fixed assets, which do not allow ensuring even normal reproduction of fixed assets, especially their active part - rolling stock.

Today, the service life of the technical resource of railways is practically expired. Therefore, there is a threat that the railway transport failures to satisfy future transportation needs of the Ukrainian economy. The capacity of individual railway sections and directions is at a critical point. The critical depreciation of the rolling stock, unbalance of the acquisition and write-off of freight cars and locomoties create a threat of failure to satisfy the needs of the industrial sectors of the economy in the transportation of goods, with the corresponding expenditures for the national budget and lowering of the index of economic development of the country.

\section{Results and Discussion}

According to the accounting reports of Ukrzaliznytsya PJSC, at the end of 2016, the deterioration level of the fixed assets in the industry was $69.4 \%$. Such a deterioration level of fixed assets does not comply with the modern principles of technological development in the industry, to a significant degree it is caused by implementation of reforms, during which the fixed assets of the railway transport have been additionally assessed, and only partly due to their upgrade.

Thus, during 2006-2016, the initial value of fixed assets of the industry increased almost 65 times and was UAH 645,200.97 billion in 2016. 


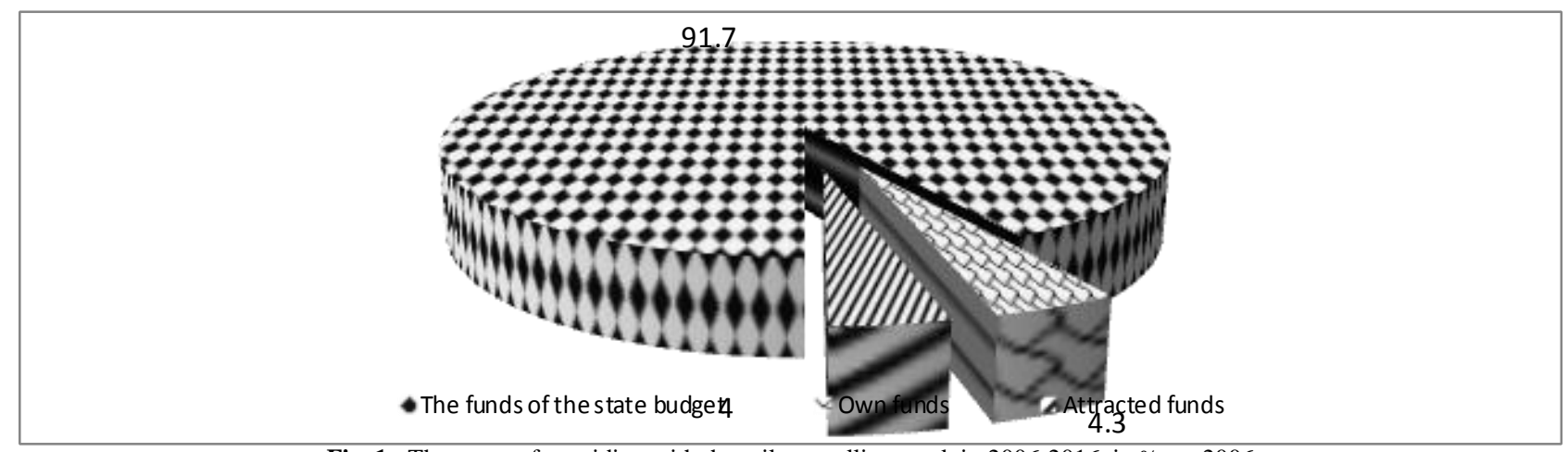

Fig. 1: The curve of providing with the railway rolling stock in 2006-2016, in \% vs. 2006

The unbalance of the scope of renovation of the rolling stock in the conditions of the critical level of its wear and tear resulted in a constant reduction of the number of the existing rolling stock units (Fig. 1).

For instance, according to the State Statistics Committee of Ukraine for the period of 2006-2016, the number of locomotives has decreased by 406 , of electric locomotives - by 89 , freight cars - by 42.7 thousand, passenger cars - by 3.3 thousand. Since 2006, the Ministry of Infrastructure of Ukraine and Ukrzaliznytsya PJSC have made several attempts to upgrade the railway rolling stock. For example, in 2008, the Integrated Railway
Renovation Program for the period from 2008-2020 was adopted and approved by the Order of the Ministry of Transport and Communications of Ukraine of October 14, 2008, which provided for the purchase of 31570 freight cars within five years, of which 18,200 are gondolas [1].

However, due to the aggravated political and, consequently, economic situation in the country, only 6,373 freight cars and 640 gondolas of the planned 31,570 freight cars, were actually manufactured at the capacities of enterprises subordinated to Ukrzaliznytsia [2, 3]. The trends of decommissioning and volumes of purchase of freight cars in 2006-2016 are shown in Fig. 2.

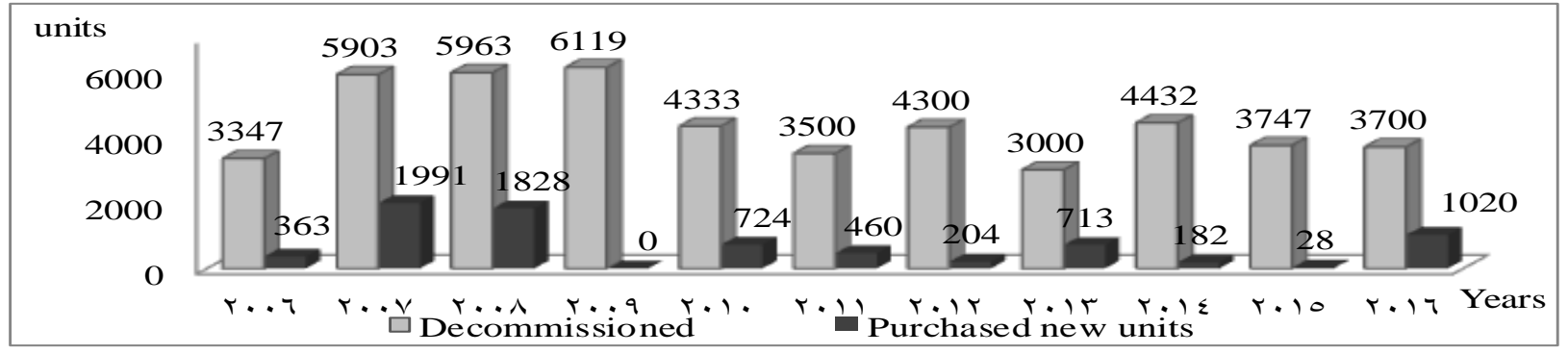

Fig. 2: The trends of renovation of the freight car stock of Ukrzaliznytsya PJSC in 2006-2016

In 2015, Ukrzaliznytsia PJSC managed to purchase only total 28 freight cars. At the end of 2016, Ukrzaliznytsia PJSC purchased 650 units from domestic manufacturers and produced 370 freight cars at its own capacities. Nine passenger cars were also purchased [4].

Annexation of Crimea and the Unannounced War on the Part of Russia Resulted in Crirical Change of Performance Indicators of the Transport Infrastructure since 2014, Namely: the Statistical

indices decreased which practically not changed for the last 23 years (the decrease of the total length of public access motor roads by 6.3 thousand. $\mathrm{km}$, of the railways by $630 \mathrm{~km}$, the number of commercial ports from 18 to 13 (operation of Yevpatoria, Kerch, Feodosia, Sevastopol, Yalta ports was terminated by the decree of the Ministry of Infrastructure of Ukraine), Ukraine lost the airports of Simferopol, Belbek, Kerch, Donetsk and Lugansk.

Assessment of financing mechanisms for the Ukrainian transport infrastructure suggests that only the budget (due to the special fund of the state budget) and credit mechanisms (attraction of international credits for transport projects) are involved. Pro- curement and financing of the Program of Locomotive Fleet Upgrade for the Ukrainian railways in 2012-2016 is shown in Table 1.

Table 1: Procurement and financing of the Program of LocomotiveFleet Upgrade for the Ukrainian railways in 2012-2016 [5]

\begin{tabular}{|l|l|l|}
\hline \multirow{2}{*}{$\begin{array}{c}\text { Total, in particular, } \\
\text { in years }\end{array}$} & $\begin{array}{c}\text { Number of loco- } \\
\text { motives, units }\end{array}$ & \begin{tabular}{l} 
Estimated $\begin{array}{l}\text { ex- } \\
\text { penditures, UAH } \\
\text { mln. }\end{array}$ \\
\cline { 2 - 3 }
\end{tabular} \\
\hline 2012 & 609 & 28674.63 \\
\hline 2013 & 104 & 3069.09 \\
\hline 2014 & 110 & 5198.5 \\
\hline 2015 & 114 & 6144.28 \\
\hline 2016 & 115 & 6825.62 \\
\hline
\end{tabular}

Increasing loans of Ukrzaliznytsia PJSC within the recent ten years together with the worsening economic situation in the industry resulted in the extremely low credit ratings, according to the Fitch rating, of the Ukrainian railway transport. The amount of the loans of Ukrzaliznytsia PJSC received from foreign investors and international financial organizations are shown in Table 2. 
Table 2: Loans of Ukrzaliznytsia PJSC received from foreign investors and international financial organizations [6]

\begin{tabular}{|c|c|c|c|c|c|}
\hline Creditor & $\begin{array}{c}\text { Year of } \\
\text { agreement }\end{array}$ & Loan purpose & $\begin{array}{l}\text { Loan amount, agreement } \\
\text { currency }\end{array}$ & Interest rate & Loan maturity, year \\
\hline EBRD & 1999 & Purchase of track equipment & 51.8 million USD & LIBOR $+1 \%$ & 2014 \\
\hline EBRD & 2004 & $\begin{array}{c}\text { Purchase of track laying } \\
\text { equipment and construction of } \\
\text { the Beskid tunnel }\end{array}$ & 120 million USD & $\mathrm{LIBOR}+1 \%$ & 2022 \\
\hline Barclay's & 2007 & $\begin{array}{l}\text { Refinancing of the existing } \\
\text { debts; general corporative } \\
\text { objectives; adding funds to } \\
\text { current assets }\end{array}$ & 550 million USD & $9.5 \%$ & 2023 \\
\hline EBRD & 2009 & $\begin{array}{l}\text { Purchase of general purpose } \\
\text { freight cars by Donetsk Rail- } \\
\text { way }\end{array}$ & 125 million USD & LIBOR $+6 \%$ & 2021 \\
\hline KEXIM & 2010 & $\begin{array}{l}\text { Purchase of } 10 \text { interregional } \\
\text { electric trains from Hyundai } \\
\text { Rotem }\end{array}$ & 260.95 million USD & LIBOR +2.6\% & 2020 \\
\hline EIB & 2014 & $\begin{array}{l}\text { Construction of the Beskid } \\
\text { tunnel }\end{array}$ & 55 million euro & $\begin{array}{l}\text { Fixed or floating rate } \\
\text { is applied for each } \\
\text { tranche }\end{array}$ & 2041 \\
\hline
\end{tabular}

Today, the long-term credit rating of the railway transport is RD, which is regarded as a limited default state [7].

Negative international credit rating hinders the investment flow to the industry and limits the renovation of the necessary number of the rolling stock units and procurement of spare parts, and, consequently, has negative effect on the technical condition, traffic safety and results in worse quality of services provided to the passengers.

According to Fig. 3, in 2016, 90.2\% of capital investment of Ukrzaliznytsia PJSC were the own funds of the industry, while $9.8 \%$ were the funds from investors and credit institutions. 2010 - 2014 were quite efficient for Ukrzaliznytsia PJSC from the point of view of attracting external investment resources, which allowed to invest about UAH21,703 million into the industry.

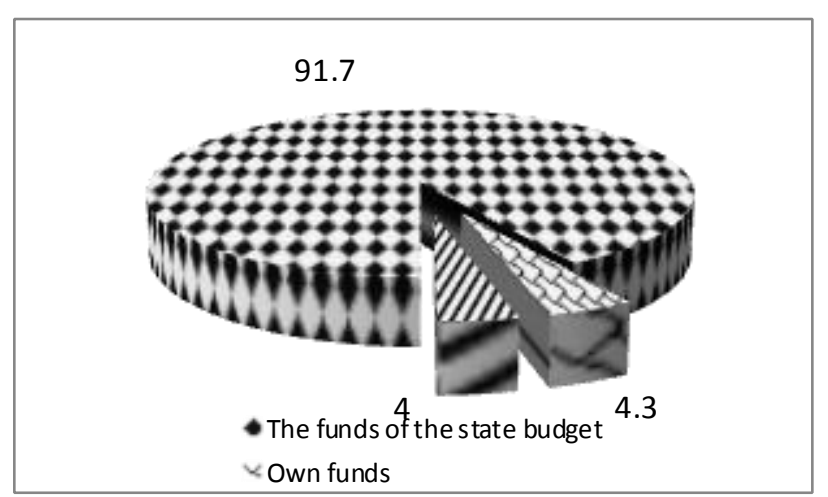

Fig. 3: Structure of capital investment of Ukrzaliznytsia PJSC in $2009, \%$

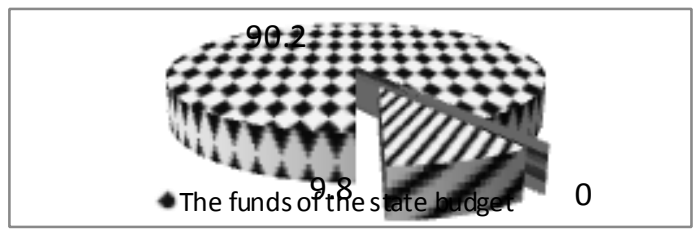

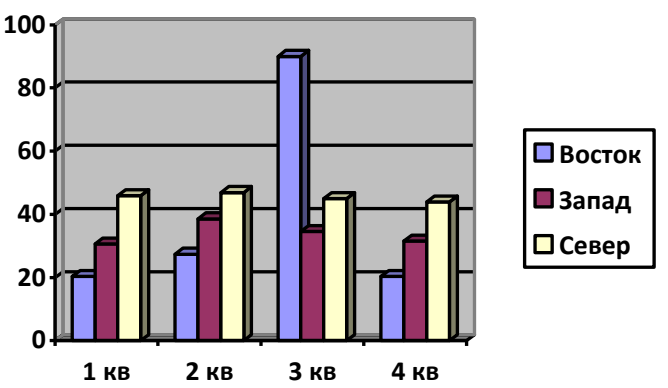

Fig. 4: Structure of capital investment of Ukrzaliznytsia PJSC in 2016 , $\%$

Regarding the spheres of capital investment in the Ukrainian railway transport, during 2009-2016, most funds were spent for capital construction in the industry, which included construction works of the Beskid Tunnel and the reconstruction of railway stations, crossings, track switches, artificial structures and earthworks, etc. In total, only in 2016, about UAH 6,885.8 million was spent in this sector (Table 3).

Thus, the analysis of the financial and investment situation with the development of the railway transport suggests that in general the industry is characterized with a low investment activity, which, without the governmental financing of the industry, causes an aggravation of the technical and technological crisis. According to experts, in fact, the actual funding amount for the railway transport development projects does not meet the real needs of the industry. According to the Strategic Railway Development Plan for the period to 2020, the total estimated demand of the railway industry for investments for renovation of fixed assets for the next 5 years is about UAH 200 billion.

Table 3: Capital investments of Ukrzaliznytsia PJSC by the purpose of use in 2009-2016 [8,9]

\begin{tabular}{|c|c|c|c|c|c|c|c|}
\hline Index & \multicolumn{7}{|c|}{ Years } \\
\cline { 2 - 8 } & 2010 & 2011 & 2012 & 2013 & 2014 & 2015 & 2016 \\
\hline $\begin{array}{c}\text { Total amount of capital investment, million UAH } \\
\text { including }\end{array}$ & 10239.9 & 14200.9 & 13973.8 & 5329.1 & 3508.2 & 4.5 & 6885.8 \\
\hline Capital construction & 6081.5 & 9848.3 & 5546.2 & 2821.8 & 1982.1 & 2844 & 2985.7 \\
\hline Purchase of fixed assets & 3839.9 & 3980.5 & 8150.9 & 2314.4 & 1367.8 & 1480.5 & 3679.6 \\
\hline Purchase of other intangible assets & 236.5 & 295.4 & 212.4 & 169.5 & 138.6 & 160.2 & 211 \\
\hline Purchase of intangible assets & 82 & 76.7 & 64.3 & 23.4 & 19.7 & 18.5 & 17.6 \\
\hline
\end{tabular}

Thus, today the development of the Ukrainian railway infrastructure is one of the priorities of the state policy, which can activate the processes of social and economic growth of the country. With the decline in industrial production and a shortage of budget funds, the state definitely cannot finance only at its own expense capital-intensive infrastructure projects for the development of railways, which requires the attraction of 
external investments and the use of alternatives to traditional governmental support of development tools (Table 4).

Table 4: Investment demand for purchase ta and upgrade of the rolling stock [10]

\begin{tabular}{|l|c|c|c|}
\hline \multicolumn{1}{|c|}{$\begin{array}{c}\text { Type of rolling } \\
\text { stock }\end{array}$} & $\begin{array}{c}\text { Purchase, } \\
\text { units }\end{array}$ & $\begin{array}{c}\text { Upgrade, } \\
\text { units }\end{array}$ & $\begin{array}{c}\text { Investment de- } \\
\text { mand, million } \\
\text { dollars }\end{array}$ \\
\hline Locomotives & 163 & 362 & 1,330 \\
\hline Freight cars & 15,753 & 46,028 & 848 \\
\hline Passenger cars & 419 & 799 & 466 \\
\hline $\begin{array}{l}\text { Electric trains } \\
\text { (sections) }\end{array}$ & 120 & 326 & 516 \\
\hline $\begin{array}{l}\text { Diesel trains } \\
\text { (cars) }\end{array}$ & 78 & 16 & 169 \\
\hline
\end{tabular}

In the context of a constant budget shortfall, the most urgent issue for Ukrainian railways is focusing on activation of innovation activity. Strengthening of the innovative component in the development projects for the transport and road complex will enable to upgrade the transport system and increase the efficiency of its operation; to increase the capacity of the transport network; to increase the transport safety level; to accelerate the integration of the Ukrainian transport system into European and world ones; and to maximize the transit potential of the country.

Introduction of innovations is quite a long and capital intensive process, which can be implemented depending mostly on level of financial support for all phases of the innovation process: from conducting studies to the implementation of innovative products in the market. The choice of financing sources for innovation is perhaps the most important issue in the process of implementing innovative activities and requires stimulation of investment into development processes and the introduction of innovations in the railway transport. Although the issues of the

development of innovation processes, innovation strategies, as well as issues related to innovation potential have been covered sufficiently in the studies of foreign and domestic researchers, some aspects still require more detailed investigation.

We believe that most of the schemes of the traditional economy in the 21 st century no longer work; therefore, alternatives should be searched for, the most obvious of which now is the cryptoe- conomy with its decentralized system. The most profitable ICOprojects, such as EOS, Filecoin, Tezos, only bolsters the belief that these successful examples will definitely be followed by others - the problem is finding them and investing into them. Development and implementation of innovations into the Ukrainian railway industry will require new approaches to the innovation financing system in the country, therefore, conducting ICO is a modern and perspective method to attract investments.

Today, more new projects and startups appear in the blockchain sphere. In this sphere ICO - a crowd funding technology for raising funds from investors - is applied ever more frequently instead of a traditional venture financing. Issues of creation and functioning of cryptocurrencies were considered in works of such researchers as S. Nakamoto [11], Alex Heid [12], issues of investment into cryptocurrencies were considered by $\mathrm{A}$. D'Alfonso, P. Langer, Z.Vandelis [13] et al. However, despite the evident results in this sphere, the substantive and theoretical aspects of the performance of the cryptographic market as a system of investment projects require further investigation and more detailed study. In general, building a cryptographic investment project is based on such main components as the idea of the project, which is defined in the business plan (generally known as WhitePaper), and the protocol (or code) which will be the basis for performance of this project. Cryptocurrencies become more common and popular also due to the open source code and the ability to monitor the activity of the project developer, the phase of solving existing tasks and problems, as well as possibility to check the quality of the code and the presence of holes and backdoors. Various combinations of elements of project organization and management are used to ensure the proper functioning of a cryptocurrency. They include such phases as distribution of tokens, confirmation of transactions (blocks), selection of the project development way, updating the cryptocurrency protocol, etc. Brief characteristics of main tools for protection of cryptocurrencies are summarized in Table 5

Table 5: Characteristic of the main tools for protection of cryptocurrencies

\begin{tabular}{|c|c|c|}
\hline $\begin{array}{l}\text { Tool for protec- } \\
\text { tion }\end{array}$ & Example of use & Main characteristic of the method \\
\hline Proof-of-work & $\begin{array}{l}\text { Hashcash, IOTA, } \\
\text { Cardano, EOS, NEM, } \\
\text { NEO, Nxt, Ripple }\end{array}$ & $\begin{array}{l}\text { Principle of protection of network system from service abuse (for example, from DDoS-attacks or } \\
\text { spamming organization), based on the need to perform some rather long work (finding a solution) on the } \\
\text { client side, the result of which can be easily and quickly validated on the server side. The main feature } \\
\text { of the calculations used is the asymmetry of time expenditures - they are significant for finding solutions } \\
\text { and very small for validation [14,15]. Such schemes are also known as a client puzzle, a computational } \\
\text { puzzle, or a CPU pricing function. }\end{array}$ \\
\hline Proof-of-stake & $\begin{array}{l}\text { BlackCoin, Nxt, Lisk, } \\
\text { Waves }\end{array}$ & $\begin{array}{l}\text { the method of protection in cryptocurrencies, in which the probability of forming the next block in } \\
\text { blockchain by a member is in proportion to the part of the payment units of the cryptocurrency, that } \\
\text { belongs to this participant, from their total number. This method is an alternative to the proof of work } \\
\text { method (PoW), in which the user with more powerful equipment has higher probability of creating the } \\
\text { next block }[14,16] \text {. }\end{array}$ \\
\hline $\begin{array}{l}\text { Proof-of-stake- } \\
\text { time }\end{array}$ & VeriCoin (VRC) & $\begin{array}{l}\text { based on the necessity to prove keeping a certain fund amount on the account within a specified time } \\
{[17,18] \text {. }}\end{array}$ \\
\hline $\begin{array}{l}\text { Proof-of- } \\
\text { importance }\end{array}$ & NEM (XEM) & $\begin{array}{l}\text { based on an algorithm that ensures the security of blockchain operation by giving priority vote to the } \\
\text { best-known members. This is a combination of wallet balance, number of incoming and outgoing trans- } \\
\text { actions, and the user's online time. Blockchain POI of cryptocurrencies takes into account these three } \\
\text { indicators to determine who will be the next creator of a new block and will receive a reward. }\end{array}$ \\
\hline $\begin{array}{l}\text { Proof-of-stake- } \\
\text { velocity }\end{array}$ & $\begin{array}{l}\text { Reddcoin (RDD), } \\
\text { Potcoin (POT) }\end{array}$ & $\begin{array}{l}\text { based on the necessity to prove holding of a certain fund amount on the account and keeping your wallet } \\
\text { online }\end{array}$ \\
\hline Proof-of-research & Gridcoin (GRC) & based on duration of holding a specified fund amount on the account \\
\hline Multiple & Decred (DCR) & $\begin{array}{l}\text { the method is based on a combination of protection methods to achieve the best organization of the } \\
\text { system }\end{array}$ \\
\hline
\end{tabular}

ICO is similar to IPO in the cryptocurrency economy. While IPO is primary public placement of a company's shares at the exchange in the traditional economy, ICO is a process of issuing own tokens by the company placing them at the cryptocurrency exchange. Due to innovation provided by blockchain technology, the cost of this process with the use of cryptocurrency exchange is dozens of times less than the cost of traditional IPO at financial exchange. A minimum IPO cost at the European exchange is about $\$ 200,000$, while the total ICO cost with trading at the cryptocurrency exchange varies from $\$ 10,000$ to $\$ 20,000$. In both cases similar results are achieved (possibility to raise investment exceeds many times the emission cost), i.e. if a com- 
pany spends about $\$ 40,000$ it may raise up to $\$ 10$ million in vestment. Only since early 2017 , about 130 cryptocurrency projects have appeared due to ICO, which raised more than 2 billion dollars investments. Conducting ICO takes in average from 2 to 8 weeks, but preparatory works are conducted for a few months (sometimes up to 6 months).

Regulation of the cryptocurrency market is a technical problem, so far few people understand how to regulate the processing taking place inside it. Virtual economy that operates via online transactions, without direct contact of a seller and a buyer, is always risky. ICO is not exclusion. According to the expert, most projects existing before 2017 may turn out to be fraudulent [19]. It happens because investment has become simpler in the virtual economy, and people invest their money very carelessly, to any company with relevantly decent presentation, without conducting adequate Due Diligence (DueD). DueD exists in the financial economy and, as a rules, is a deep analysis of the investment object and submitting a report. The analysis includes the evaluation of investment risks, comprehensive investigation of the company's business, complex verification of financial position and market position, competence and previous experience of the involved team. Only experienced investors can afford conducting DueD who order services of the relevant experts. In the cryptocurrency economy and ICO, Due Diligence is often conducted tenuously, which also results in investing into projects which are not related to any real business. The example is crowd investing of all types of lotteries and casinos. To secure the investors, like in the traditional financial market, new players appear in the cryptocurrency market - rating agencies. Such agencies conduct independent Due Diligence, analyze all available information on the companies which are entering the cryptocurrency exchange and publish the findings from the investigation as an independent rating review stating strengths and weaknesses of the projects. The company providing ICO launch service cooperates with rating agencies to minimize the risks of investors.

For example, Ambisafe concluded a partner agreement with ICORating agency that provide additional reliability of joint projects. ICORating conducts research of all aspects of the project which are behind the individual cryptocurrency financial instrument. The company analyzes investment risks of the project which involves ICO, by the following aspects: business model (its relevance, strengths and weaknesses); market niche (potential and course of development of the chosen market niche for building the business); team (business experience in the traditional market segment, in the blockchain industry, experience of blockchain developments); competition (competitive pressure level from the companies with similar business models from the traditional market segment and blockchain economy); technical background (availability and quality of a prototype or an exit code); analysis of the community feedback; and many other aspects. Thus, open access will be provided for investors to see how risky each individual investment is.

Another way to protect against potential fraud is by cryptographic escrow implemented through multi-sig wallet and independent escrow agents. This means that the company collects money indirectly, through third parties. The funds are collected to a multi-sig wallet, access to which is only authorized for deposit agents, which in turn provides additional protection. Thus, the company cannot spend the collected money on their own without the agent's digital signature. The deposit agent's functions include checking if the terms and conditions of the offer are fulfilled by the company and if investors keep to the terms and obligations. Only if the stated conditions are observed, the company will get access to certain amounts from the Multi-sig wallet. This is how it looks in prsctie: the company raises $\$ 1$ million. The plan for implementing a business model is divided into 10 periods. The company receives first $\$ 100,000$ from the Multi-sig wallet right after the end of the fund raising phase. Then the deposit agent will monitor the fulfillment of the stated conditions, fairness of the issuing company, compliance with the terms and conditions and, in case of successful completion of the first phase of the plan, will authorize the next tranche. If the company fails to fulfill its obligations, the money either remains locked in the wallet until the obligations are fulfilled or is returned to the investors. Thus, conducting ICO for individual investment projects in the railway transport provides some advantages to investors: ICO provides great opportunities for promising projects: starting from the second most popular cryptocurrency after bitcoin and up to the creation of a platform for blockchain-based services, all this was done within the ICO; ICO does not require extra documentation (the main and essential document for ICO is the White Paper, which contains all the details of the project, and the ICO is a form of crowd funding, hence anyone can read this technical document and choose the most attractive project to invest); creation of a new community (the project creators may create a new community around their projects. Presence of the community gives the product credibility. The community members' opinions are valuable with regard to individual projects which also favours the business integrity of project creators. In this respect, Ukrzaliznytsya PJSC is the national freight and passenger carrier which satisfies the needs for safe and high-quality railway transportation, ensures the efficient functioning and development of the Ukrainian railway transport. Thus, a potential investor would hardly doubt the reality of this project; access to potential tokens in the early phases, despite the low price at the beginning of the project.

\section{Conclusion}

What participants benefit from creation of ICO? First, it is Ukrzaliznytsya PJSC itself that can raise investors' funds by selling tokens. Secondly, ICO investors will profit because they buy tokens at the lowest price and can further sell them much better. The proposed model of investment support for the introduction of innovations in the railway transport will not only provide financing for technological upgrade of the railway industry, change its production facilities for the production of high-tech innovative products, but also implement socially significant projects of development of the country, to obtain a number of economic benefits for each member of this partnership.

It should be noted that the blockchain economy is developing very rapidly, and today the growing ICO market repeats the history of the formation and development of the traditional stock market, only significantly faster. Some projects that use ICO today have the potential to grow over time into huge businesses and to repay the investments many times. Many investors today recall the time when such companies as Apple, Amazon or Google began with IPOs, and dream what capital they could have gained if they had invested in these companies then. At the moment, the ICO market gives another chance to become part of the success story of the new economy projects, both for investors and for companies whose founders aspire to create really important projects. Strengthening of the innovative component in the development projects for the transport and road complex will enable to upgrade the transport system and increase the efficiency of its operation; to increase the capacity of the transport network; to increase the transport safety level; to accelerate the integration of the Ukrainian transport system into European and world ones; and to maximize the transit potential of the country.

\section{References}

[1] "Ukrzaliznytsya" znachno vidremontuye zaliznychnyy rukhomyy sklad do 2020 roku [Electronic resource]. - Access mode: http://www.magistral-uz.com.ua/print/news/ukrzaliznicja-do2020-roku-suttevo-onovit-zaliznic.html, last visit:18.06.2018

[2] Ukrzaliznytsya znachno vidremontuye zaliznychnyy rukhomyy sklad do 2020 roku, available online: http://www.magistral- 
uz.com.ua/print/news/ukrzaliznicja-do-2020-roku-suttevo-onovitzaliznic.html. - Name from the screen; Ponomarenko O. V. Prospects for improvement of the technical state of the railway car fleet of the Ukrainian railways / O. V. Ponomarenko // Nauka ta progres transportu. - 2017. - No. 1 (67). - P. 88-95., last visit:15.06.2018

[3] Vpershe za ostanni roky "Ukrzaliznytsya" prydbala velyku kil'kist' vantazhnykh i pasazhyrs'kykh vahoniv - Wojcech Balczun, available online: http://www.uz.gov.ua/press_center/up_to_date_topic/442185/., last visit:15.06.2018, last visit:16.06.2018.

[4] Litvin Y O Metody gosudarstvennogo regulirovaniya sel'skogo khozyaystva / Y O Litvin // Scientific reporter of the Academy of Municipal Management. Series: Management . - 2012. - Iss. 4. P. 127-135.

[5] Kredity inostrannykh investorov i mezhdunarodnykh finansovykh institutov, available online: http://www.uz.gov.ua/about/investors/borrowings/credits//, last visit:14.06.2018.

[6] Official website of Ukrainska zaliznytsya PJSC, available online: http://www.uz.gov.ua/about/investors/credit_ratings/, last visit: 13.06.2018.

[7] Polnovodnoye rukovodstvo ICO, available online: //http://www.invest-rating.ru/financial-encyclopedia/?id=6371, last visit: 15.06.2018.

[8] Yarmolitska O V Economic principles of innovative and investment representation of the fixed production assets of railway transport enterprises: dissertation for the scientific degree of the candidate of economic sciences $(\mathrm{PhD})$; specialty: 08.00.04 - economics and business management (by types of economic activities) / Yarmolitska Olga Vasylivna. - Kyiv, 2016. - 237 p.

[9] Analitychnyy zvit pro vykonannya finansovoho planu PAT "Ukrzaliznytsya" na 2016 rik [Electronic resource]. - Access mode: http://www.uz.gov.ua/about/investors/financial_statements/. -

[10] Osnovni aspekty stratehiyi rozvytku PAT "Ukrzaliznytsya" na 2017-2021 roky [Electronic resource]. - Access mode: http://www.uz.gov.ua/files/file/Strategy_Presentation_fin1.pdf.

[11] Nakamoto S Bitcoin: A Peer-to-Peer Electronic Cash System, available online: https://bitcoin.org/bitcoin.pdf.

[12] What is Proof-of-Work и Proof-of-Stake? [E-resource] // ForkLog journal. - Access mode: http://forklog.com/chto-takoeproof-of-work-i-proof-of-stake.

[13] Heid A Analysis of the Cryptocurrency Marketplace [E-resource] / Alex Heid, available online: https://bravenewcoin.com/assets/Whitepapers/HackMiamiAnalysis-of-the-Cryptocurrency- Marketplace.pdf.

[14] D'Alfonso A The Future of Cryptocurrency An Investor's Comparison of Bitcoin and Ethereum / A D'Alfonso, P Langer, Z Vandelis // Ryerson University. - 2016., available online: http://www. economist.com/sites/default/files/ the_future_of_cryptocurrency.pdf.

[15] Cryptocurrencies Without Proof of Work. available online: https://link.springer.com/chapter/10.1007/978-3-662-53357-4_10, last visit:13.06.2018

[16] Proof of ownership. «Proof-of-Stake Algorithmic Methods: A Comparative Summary». Social Science Research Network (SSRN). 11-03-2018.

[17] Vitalik Buterin. A Proof of Stake Design Philosophy. - Access mode: https://medium.com/@VitalikButerin/a-proof-of-stakedesign-philosophy-506585978d51

[18] Vitalik Buterin. Proof of Stake: How I learned to love weak subjectivity. blog.ethereum.org, 2014

[19] A comprehensive guide to ICO, available online: http://www.invest-rating.ru/financial-encyclopedia/?id=6371, last visit:18.06.2018. 